(C) 2001 The Chemical Society of Japan

一技術論文——

\title{
分子集合体のサイズに対する第四級アンモニウム塩型カチオン 界面活性剂の化学構造と温度の影響1)
}

\author{
(2000 年 11 月 20 日受理)
}

堀内照夫* $*^{*}$ 真島利明 $\cdot$ 吉井 徹 $\cdot$ 田村隆光

\begin{abstract}
サリチル酸ナトリウム共存下での第四級アンモニウム塩型カチオン界面活性剂の配管抵抗減少効果と 分子集合体の長さに対する温度の影響を，アルキル基の炭素鎖長および2-ヒドロキシエチル基の置換 数を変えたカチオン界面活性剂について検討した． NaSal/cationics 系水溶液のキャラクタリゼーショ ンを DR 効果, 圧力損失, 第一法線応力差 $\left(N_{1}\right)$ 抢よび粒子径で行った結果, $\mathrm{NaSal} /$ cationics 系水溶液 の分子集合体の長さが $40 \mathrm{~nm}$ 以上のとき，65-80\%の高い DR 効果を示したが， $30 \mathrm{~nm}$ 以下では， $\mathrm{DR}$ 効果は 5 -7\%であった，以上の結果，DR 効果発現のために，分子集合体の長さが重要な役割を果た していると思われる。
\end{abstract}

\section{1 緒 言}

近年, カチオン界面活性剂水溶液中で形成される分子集合体の 中で，棒状ミセルのような高次分子集合体 ${ }^{3)-5)}$ は管内の乱流を制 御し，管壁と流体間の摩擦係数を低減する現象が多数報告されて いる(6)-8). そして，この界面活性剂による配管抵抗減少技術 (DR 技術)の地域冷暖房システムへの応用開発が盛んに研究されてい $ろ^{9)}$.

サリチル酸ナトリウム/カチオン界面活性剂系水溶液中で形成 される分子集合体はアルキル鎖長や温度により著しく変化する転 移濃度 $\left(C_{\mathrm{t}}\right)$ により規定され, 球状ミセル $\rightarrow$ 棒状ミセル転移現象 を示すことが報告されている ${ }^{6)}$.転移濃度以下であると, 球状ミ セルが支配的となり，DR 効果は発現しない。

棒状ミセルによる DR 効果発現の作用機構に関しては SANS による棒状ミセルの管内流の配向挙動10)11)ならびにせん断誘起 構造 (shear-induced structure; SIS) 形成性7)12)-14)の観点から盛 んに研究されている. しかしながら棒状ミセルの絡み合いはミセ ル間の相互作用が直接ミセル自身の解離, 再結合に関与するた め, そのダイナミクスは複雑で未知の点が多い.

本論文では, NaSal/cationics 系水溶液の DR 効果に対する界 面活性剂の分子集合体のサイズおよび温度の影響について報告す る.

\section{2 実験}

\section{1 試料}

テトラデシルビス (2-ヒドロキシエチル)メチルアンモニウム クロリド (TDHMA), ヘキサデシルビス (2-ヒドロキシエチル) メチルアンモニウムクロリド(HDHMA), オクタデシルビス (2ライオン株式会社研究開発本部物質科学センター, 1320035 東京都江戸川区平井 7-13-12
ヒドロキシエチル)メチルアンモニウムクロリド(ODHMA)，ト リメチル (cis-9-オクタデセニル)アンモニウムクロリド (TMODA)，2-ヒドロキシエチルジメチル ( cis-9-オクタデセニル)アン モニウムクロリド(HDMOA), ビス (2-ヒドロキシエチル)メチ ル (cis-9-オクタデセニル)アンモニウムクロリド (HMODA), ト リス (2-ヒドロキシエチル) (cis-9-オクタデセニル)アンモニウム クロリド (THODA), およびサリチル酸ナトリウム $(\mathrm{NaSal})$ は前 報2)のもの用いた.

2.2 測 定

2.2.1 レオロジー測定 : 供試料溶液の調製, その試料溶液の 粘性係数 $(\eta)$ 抢よび第一法線応力差 $\left(N_{1}\right)$ の測定は既報 ${ }^{2)}$ に準じて 行った.

2.2 .2 会合体の長さ: $\mathrm{NaSal} /$ cationics 系水溶液の会合体の長 さは光散乱光度計 DLS-700 (大塚電子侏) を用いて測定した. 本 装置の測定原理は光子相関分光法に基づくものである. 今, 供試

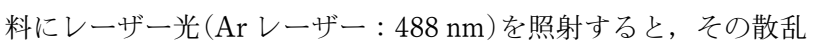
光は溶液中の分散粒子の速度に応じて, 連続的な散乱強度として 検出される.すなわち, 小さな分散粒子は速く動き, 高い変動振 動を, また, 大きな分散粒子はゆっくり動き, 低い変動振動を与 える. この変動信号 (強度) は自己相関関数によって与えられ, 自 己相関関数から減哀定数 $(\Gamma)$ が求められる. そして, この減衰定 数を用いて拡散係数 $(D)$ を算出する. 流体力学的径(ストークス 径 $(d))$ は (1)式によって与えられる.

$$
d=k T /\left(3 \pi \eta_{0} D\right)
$$

ここで, $k$ はボルッマン定数, $T$ は絶対温度, $\eta_{0}$ は溶媒の粘度 である。

2.2.3 DR 効果の評価: カチオン界面活性剂水溶液の配管抵 抗減少効果 (DR 効果) は既報2)に準じて行った. 


\section{3 結果および考察}

\section{$3.1 \mathrm{NaSal} / \mathrm{HMODA}$ 系水溶液の圧力損失の温度依存性}

前報2)で，カチオン界面活性剂の DR 効果に対するアルキル基 の炭素鎖長抢よび 2-ヒドロキシエチル基の置換数の影響につい て報告した，流動条件下で，カチオン界面活性剂水溶液の分子集 合状態を知るため, $\mathrm{NaSal} /$ cationics 系水溶液の圧力損失のアレ ニウスプロットを行った．その一例として，Fig. 1 および Fig. 2 に, NaSal/HMODA 系水溶液抢よび水の圧力損失のアレニウス プロットを示す

水単独系の場合, Fig. 2 に示すように, 温度 $(1 / T)$ に対する圧 力損失 $(\Delta P)$ は単調な右上がりの直線を示し, 屈曲点は観察され なかったそそして，流速が速くなるにつれて，その圧力損失 $(\Delta P)$ は単調に上昇傾向を示した。しかし，NaSal/HMODA 系 水溶液の場合, Fig. 1 に示すように, 温度 $(1 / T)$ に対する圧力損 失 $(\Delta P)$ は $60{ }^{\circ} \mathrm{C}$ 以上で, 流速によらず左上がりの直線を示し た。しかし， $60^{\circ} \mathrm{C}$ 以下の温度領域に扔いて，流速が $1.36 \mathrm{~m} / \mathrm{s}$ 以 下では，その圧力損失 $(\Delta P)$ の值は水より小さく，ほぼ一定の值 を示した。しかし流速が $1.70 \mathrm{~m} / \mathrm{s}$ 以上になると，ある温度で屈 曲点を持つ右上がりの直線を示した。 そして流速がさらに増加す ると，この屈曲点は高温側にシフトする興味ある結果を示した。 このことは配管中の流動条件下で, NaSal/HMODA 系水溶液の 粘弾性に変化が生じたことを示唆している.

\section{$3.2 \mathrm{NaSal} / \mathrm{HMODA}$ 系水溶液の第一法線応力差 $\left(N_{1}\right)$ の温度} 依存性

NaSal / HMODA 系水溶液のせん断誘起構造 (shear-induced structure; SIS)の形成性に対する温度の影響を知るため，その水 溶液の第一法線応力差 $\left(N_{1}\right)$ を測定した.

Fig. 3 に示すように, $10{ }^{\circ} \mathrm{C}$ に抢いては，NaSal/HMODA 系水 溶液の第一法線応力差 $\left(N_{1}\right)$ はずり速度の増加とともに増加し,

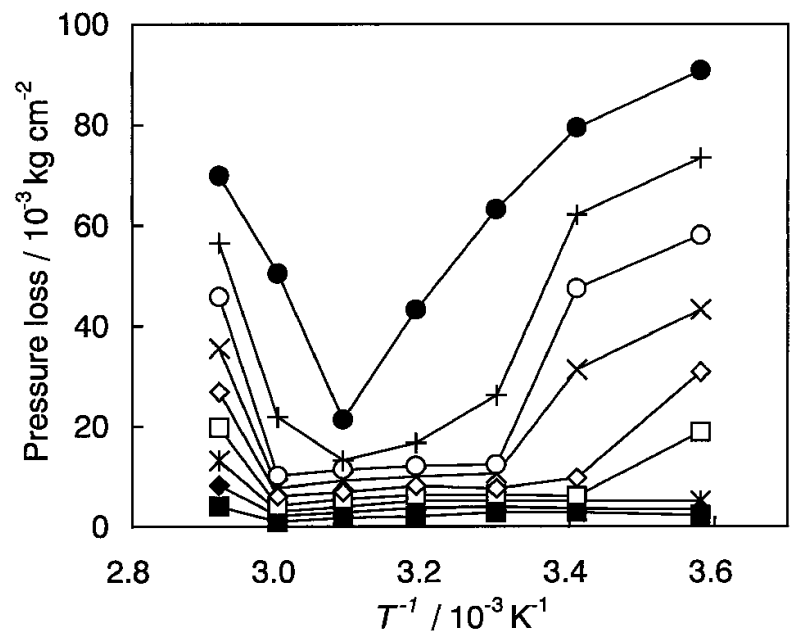

Fig. 1 Plots of pressure loss $(\Delta P)$ for NaSal/HMODA solutions against $1 / T$

Molar ratio of NaSal/HMODA $=1.5$. Concentration of HMODA: $1000 \mathrm{ppm}$. Flow rate $(\mathrm{m} / \mathrm{s})$ : $\mathbf{\square} ; 0.68$, ; $1.02, * ; 1.36, \square ; 1.70, \diamond ; 2.04, \times ; 2.38, \bigcirc ; 2.72,+$; $3.06,0 ; 3.40$.
ずり速度，約 $800 \mathrm{~s}^{-1}$ でほぼ一定の值を示した。これは NaSal/ HMODA 系水溶液中の棒状ミセルのような高次の分子集合体が 流動条件下で伸長 ·変形し, せん断誘起構造が形成したことを示 唆している。しかし, 温度が上昇するにつれて, NaSal/HMO$\mathrm{DA}$ 系水溶液の第一法線応力差 $\left(N_{1}\right)$ は減少し, $40{ }^{\circ} \mathrm{C}$ で第一法線 応力差 $\left(N_{1}\right)$ は負の值となり, ずり速度とともに減少した。この ことは NaSal/HMODA 系水溶液が粘弾性溶液からニュートン流 体へと変化したことを示唆している。この結果は以下のように考 えられる. NaSal/HMODA 系水溶液は一般的な界面活性剂水溶 液と同様に臨界ミセル濃度 $(\mathrm{CMC})$ 以上で, 球状ミセルを形成す る。この球状ミセルはその CMC 上り高いある濃度(転移濃度；

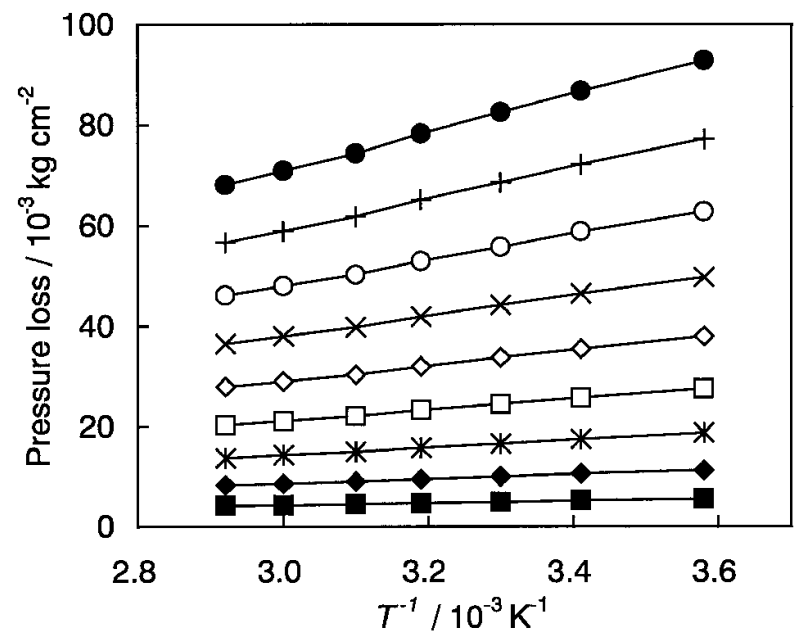

Fig. 2 Plots of pressure loss $(\Delta P)$ for water against $1 / T$. Flow rate $(\mathrm{m} / \mathrm{s}): \square ; 0.68, \nabla ; 1.02, * ; 1.36, \square ; 1.70$, $\diamond ; 2.04, \times ; 2.38, \bigcirc ; 2.72,+; 3.06, \mathbf{O} ; 3.40$.

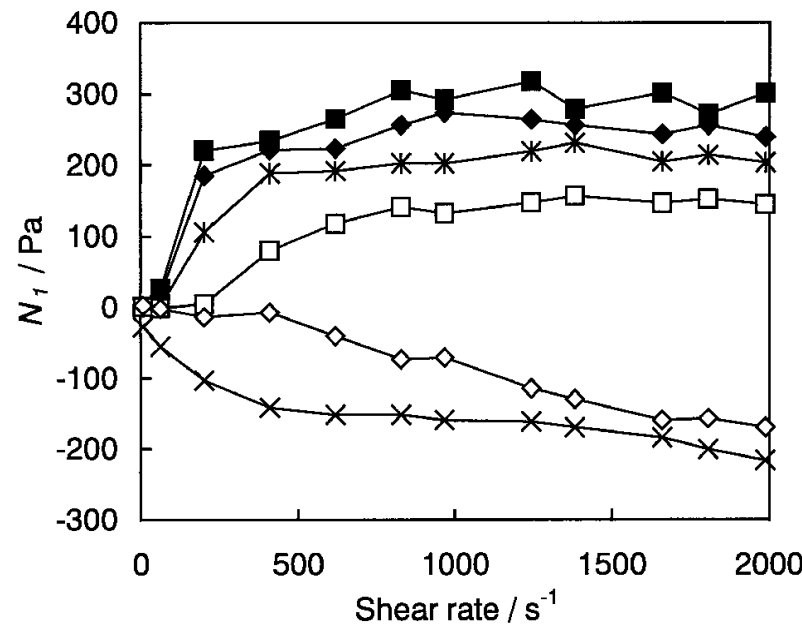

Fig. 3 Effect of temperature on first normal stress difference $\left(N_{1}\right)$ for HMODA complexed with NaSal. Molar ratio of NaSal/HMODA $=1.5$. Concentration of HMODA: 1000 ppm.

Temperature $\left({ }^{\circ} \mathrm{C}\right): \square ; 10, \diamond ; 25, * ; 30, \square ; 35, \diamond ; 40$, $\times ; 55$. 
$C_{\mathrm{t}}$ ) 以上で棒状ミセルに転移する. この棒状ミセルの形成を決定 する転移濃度 $\left(C_{\mathrm{t}}\right)$ は温度が高くなると著しく増加し, かつ棒状 ミセルの長さも減少することが報告されている6 ${ }^{6}$.したがって, 所定濃度の NaSal/HMODA 系水溶液中の棒状ミセルは温度が高 くなるにつれて, 球状ミセルへと転移し, かつ残存している棒状 ミセルの長さも減少するため, せん断誘起構造 (SIS)の形成が抑 制されたものと思われる.

以上の結果から, SIS の形成を誘起する粘弾性溶液の性質に $\mathrm{NaSal} / \mathrm{HMODA}$ 系水溶液中の分子集合体の長さが重要な役割を 果たしていることが示唆された.

\section{$3.3 \mathrm{NaSal} /$ cationics 系水溶液中の分子集合体の長さに対す}

\section{る温度の影響}

アルキル基の炭素鎖長および 2-ヒドロキシエチル基の置換数 を変えたカチオン界面活性剤を用いて NaSal/cationics 系水溶液 中の分子集合体の長さに対する温度の影響を調べた.

Fig. 4 に 2-ヒドロキシエチル基の置換数を 2 個に固定し，ア ルキル鎖長が異なるカチオン界面活性剤の分子集合体の長さに対 する温度の影響を示す.

$\mathrm{NaSal} /$ cationics 系水溶液中の分子集合体の長さは, $\mathrm{R}=\mathrm{C}_{16}$ で は温度 $40{ }^{\circ} \mathrm{C}, \mathrm{R}=\mathrm{C}_{18}$ では温度 $50{ }^{\circ} \mathrm{C}$ に極大值を持つ曲線となっ た。また，アルキル鎖長が不飽和の $c i s-9$-オクタデセニル基 $(\mathrm{R}$ $\left.=\mathrm{C}_{18: 1}\right)$ では, $\mathrm{R}=\mathrm{C}_{18}$ の場合と同じように, 温度 $50{ }^{\circ} \mathrm{C}$ で極大 值を持つ曲線となった。しかし, $20-70{ }^{\circ} \mathrm{C}$ の温度範囲で, $\mathrm{C}_{18: 1}$ の分子集合体の長さは $\mathrm{C}_{18}$ より小さかった. 分子集合体の長さが $20{ }^{\circ} \mathrm{C}$ から極大值を示す温度に至る過程でわずかに増加する理由 は，臨界充填パラメーター $(\mathrm{CPP})$ の概念から説明できる。すな わち，用いた界面活性剤はいずれも 2 個の 2-ヒドロキシエチル 基を持っている．温度上昇とともに，2-ヒドロキシエチル基の まわりの水和水が脱水される. そのため, カチオン界面活性剤の 親水基の断面積が減少するので，CPP は大きくなるため，分子 集合体が増加したと推定される．しかし，極大值を示す温度より

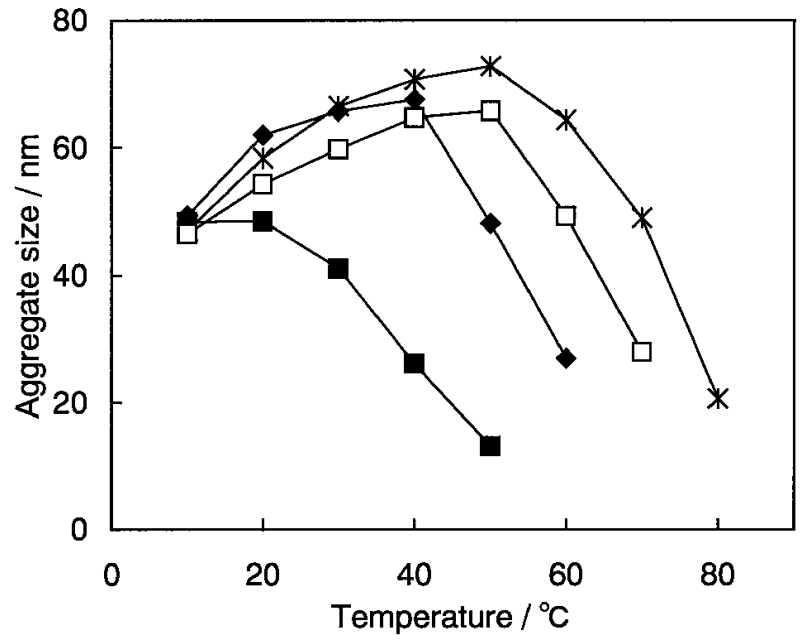

Fig. 4 Effect of temperature on aggregate size for cationics with various alkyl chain length complexed with NaSal. Molar ratio of $\mathrm{NaSal} /$ cationics $=1.5$. Concentration of cationics: 1000 ppm. Symbols: $\square$; TDHMA, $\diamond$; HDHMA, * ; ODHMA, $\square$; HMODA.
さらに温度が上昇すると, $\mathrm{NaSal} /$ cationics 系水溶液の球状ミセ ル 棒状ミセル転移を示す転移濃度が増加する。 そのため, 温度 上昇とともに, 棒状ミセル数が減少し, 球状ミセル数が支配的と なるので，見掛けの分子集合体の長さは著しく減少する.

一方, $\mathrm{R}=\mathrm{C}_{14}$ では, 分子集合体の長さが極大值を持たず，温 度とともに減少したことは, NaSal/TDHMA 系水溶液の球状ミ セル $\rightarrow$ 棒状ミセル転移を示す転移濃度が高く, かつ温度上昇とと もに増加するため, すでに $20{ }^{\circ} \mathrm{C} て ゙$ 棒状ミセルよりむしろ球状ミ セルの寄与率が大きいため, 温度とともに, 分子集合体の長さが 減少したものと思われる．このことは Fig. 5 に示すアルキル鎖 長の異なるカチオン界面活性剤の第一法線応力差 $\left(N_{1}\right)$ の結果か らも示唆される.

カチオン界面活性剤のアルキル鎖長が $\mathrm{C}_{16}, \mathrm{C}_{18}, \mathrm{C}_{18: 1}$ では, そ れぞれの第一法線応力差 $\left(N_{1}\right)$ はずり速度とともに上昇し, せん 断誘起構造 (SIS)の形成を示したが， $\mathrm{C}_{14}$ では，ずり速度が 1200 $\mathrm{s}^{-1}$ 以上で初めて第一法線応力差 $\left(N_{1}\right)$ がわずかに発現した。

一方, Fig. 6 にアルキル鎖を cis-9-オクタデセニル基 $\left(\mathrm{C}_{18: 1}\right)$ に固定し, 異なる 2 -ヒドロキシエチル基の置換数のカチオン界 面活性剤の分子集合体の長さに対する温度の影響を示す。

分子集合体の長さは, いずれの場合も, 温度 $50{ }^{\circ} \mathrm{C}$ で極大值を 持つ曲線となった． 2 -ヒドロキシエチル基の置換数が $0-2$ 個の 場合, その分子集合体の長さは $50{ }^{\circ} \mathrm{C}$ までの温度範囲でほぼ同じ 傾向を示した. しかし，2-ヒドロキシエチル基を 3 個置換した THODA の分子集合体の長さは 2-ヒドロキシエチル基の置換数 が 0-2 個のものと比較して, いずれの温度条件においても小さ い值となった。

これは Fig. 7 に示す 2-ヒドロキシエチル基の置換数の異なる 第一法線応力差 $\left(N_{1}\right)$ の結果から示唆されるように，2-ヒドロキ シエチル基が 3 個置換されると, その立体障害のため, 高次分 子集合体の形成が抑制されたものと思われる.

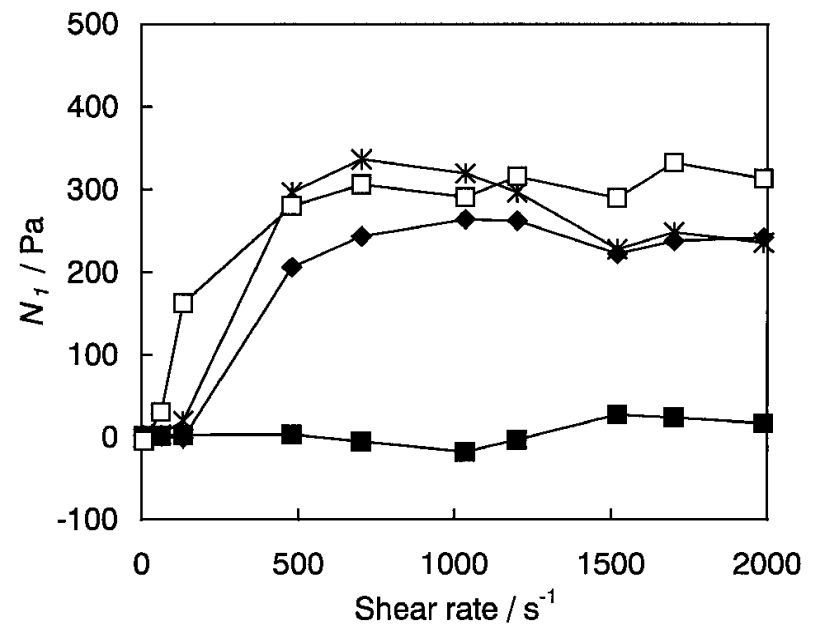

Fig. 5 Effect of alkyl chain length on first normal stress difference $\left(N_{1}\right)$ for $\mathrm{NaSal} /$ cationics solutions at $25{ }^{\circ} \mathrm{C}$. Molar ratio of NaSal $/$ cationics $=1.5$. Concentration of cationics: 1000 ppm. Symbols: $\mathbf{\square}$; TDHMA, $\diamond$; HDHMA, $*$; ODHMA, $\square$; HMODA. 


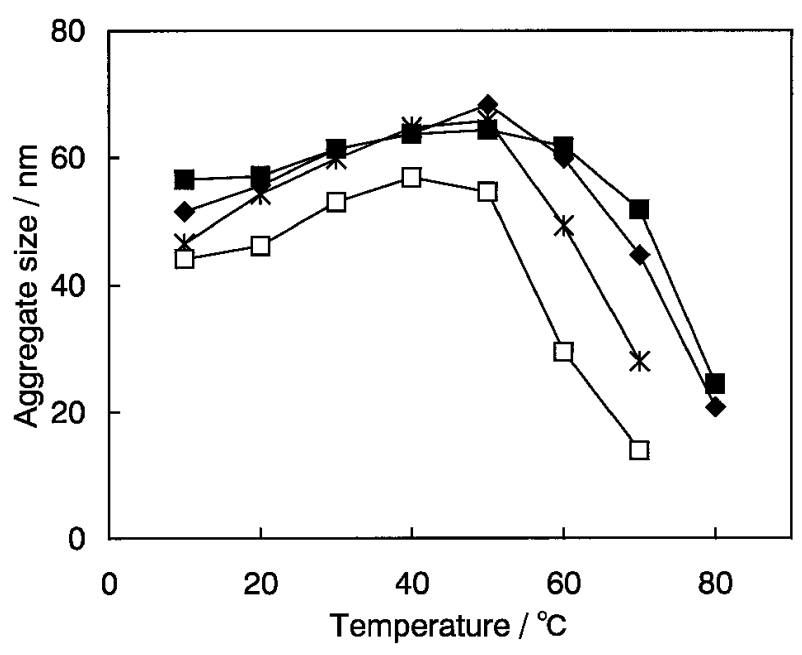

Fig. 6 Effect of temperature on aggregate size for cationics with various 2 -hydroxyethyl group numbers complexed with NaSal.

Molar ratio of $\mathrm{NaSal} /$ cationics $=1.5$. Concentration of cationics: $1000 \mathrm{ppm}$.

Symbols: $\square$; TMODA, $\diamond$; HDMOA, * ; HMODA, $\square$; THODA.

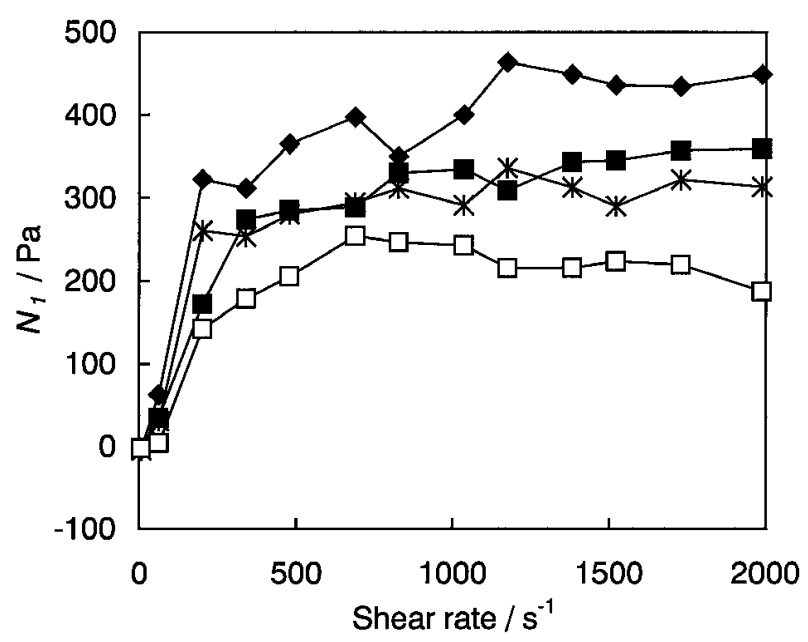

Fig. 7 Effect of 2-hydroxyethyl group numbers on first normal stress difference $\left(N_{1}\right)$ for $\mathrm{NaSal} /$ cationics solutions at $25{ }^{\circ} \mathrm{C}$.

Molar ratio of NaSal $/$ cationics $=1.5$. Concentration of cationics: $1000 \mathrm{ppm}$.

Symbols: $\square$; TMODA, $\diamond$; HDMOA, * ; HMODA, $\square$; THODA.

\section{4 分子集合体の長さと DR 効果}

Fig. 8 に所定温度における NaSal/cationics 系水溶液中の分子 集合体の長さとそのときの最大 DR 効果のランダムプロットの関 係を示す。

$\mathrm{NaSal} /$ cationics 系水溶液の DR 効果は分子集合体の長さに応 じ, 不連続に変化している. すなわち, $\mathrm{NaSal} /$ cationics 系水溶 液中の分子集合体の長さが $40 \mathrm{~nm}$ 以上のとき, 高い $\mathrm{DR}$ 効果が

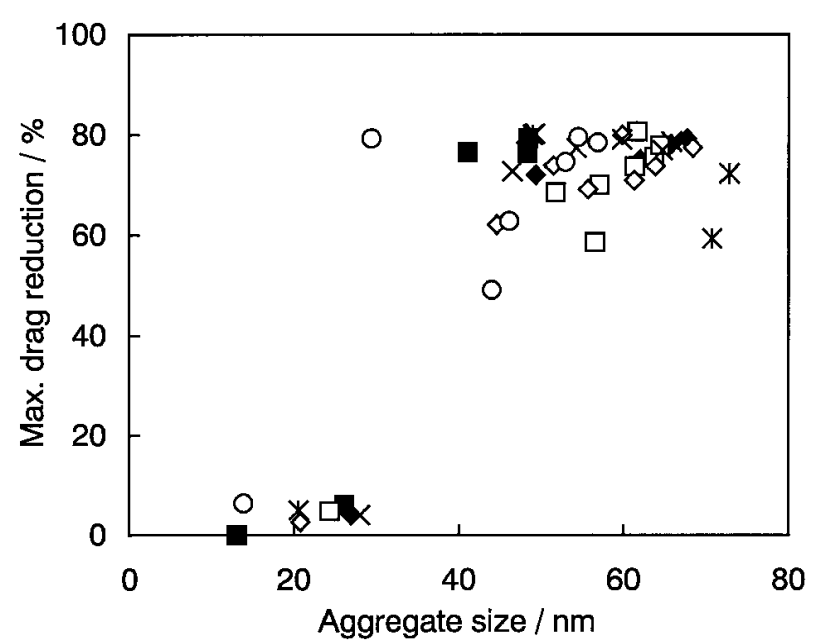

Fig. 8 Random plots of maximum DR effect as a function of aggregate size for $\mathrm{NaSal} /$ cationics solutions at a given temperature.

Molar ratio of $\mathrm{NaSal} /$ cationics $=1.5$. Concentration of cationics: $1000 \mathrm{ppm}$.

Symbols: $\mathbf{\square}$; TDHMA, $\diamond$; HDHMA, * ; ODHMA, $\square$; TMODA, $\diamond$; HDMOA, $\times$; HMODA, $\bigcirc$; THODA.

発現するが，分子集合体の長さが $30 \mathrm{~nm}$ 以下では, DR 効果はほ とんど発現しなかった.

以上の結果, $\mathrm{DR}$ 効果の発現のためには, $40 \mathrm{~nm}$ 以上の分子集 合体が存在していることが重要であると結論された.

\section{4 結 論}

サリチル酸ナトリウム共存下での第四級アンモニウム塩型カチ オン界面活性剂の配管抵抗減少効果と分子集合体の長さに対する 温度の影響をアルキル基の炭素鎖長抒よび 2-ヒドロキシエチル 基の置換数を変えたカチオン界面活性剤について検討した，その 結果, $\mathrm{NaSal} /$ cationics 系水溶液では分子集合体の長さが $40 \mathrm{~nm}$ 以上のとき， $65-80 \%$ の高い DR 効果を示したが，分子集合体 の長さが $30 \mathrm{~nm}$ 以下では, DR 効果は 5-7\%であった，以上の 結果, DR 効果発現のために, 分子集合体の長さが重要な役割を 果たしていると思われる.

1）この報文を“第四級アンモニウム塩型カチオン界面活性 剂水溶液の配管抵抗減少効果(第 2 報)”とする.

2）前報(第 1 報), 堀内照夫, 吉井徹, 真島利明, 田村隆 光, 菅原 均, 日化, 2001, 415 .

3) T. Shikata, Y. Sakaiguchi, H. Uragami, A. Tamura, H. Hirata, J. Colloid Interface Sci., 119, 29 (1987).

4) Y. Sakaiguchi, T. Shikata, H. Urakami, A. Tamura, H. Hirata, Colloid Polym. Sci., 265, 750 (1987).

5) 加藤 直, 電気化学, $64,862(1996)$.

6) D. Ohlendorf, W. Interthal, H. Hoffmann, Rheol. Acta, 25, 468 (1986).

7) H. Hoffmann, G. Ebert, Angew. Chem. Int. Ed. Engl., 27, 902 (1988).

8) B. Lu, X. Li, L. E. Scriven, H. T. Davis, Y. Talmon, J. L. Zakin, Langmuir, 14, 8(1998).

9）ダウケミカル， 日特表 昭 58-501822(1983)；へキスト, 日特開昭 59-46246（1984）; ヘキスト, 日特開昭 60- 
$158145(1985)$.

10) H. W. Bewersdorff, J. Dohmann, J. Langowski, P. Lindner, A. Maack, R. Oberthur, H. Thiel, Pysica B, 156 \& 157, 508(1989).

11) P. Lindner, H. W. Bewersdorff, R. Heen, P. Sittart, H. Thiel, J. Langowski, R. Oberthur, Prog. Colloid Polym.
Sci., 81, 107(1990).

12) Y. Hu, E. F. Matthys, Rheol. Acta., 35, 470(1996).

13) Y. Hu, E. F. Matthys, J. Rheol., 41, 151(1997).

14) B. Lu, X. Li, J. L. Zakin, Y. Talmon, J. Non-Newtonian Fluid Mech., 71, 59(1997).

\title{
Effect of Chemical Structure of Quaternary Ammonium Salt-type Cationic Surfactants and Temperature on Aggregate Size
}

\author{
Teruo Horiuchi*, Toshiaki Majima, Toru Yoshi and Takamitsu Tamura \\ Material Science Research Center, Lion Corporation; 13-12, Hirai 7-Chome, \\ Edogawa-ku, Tokyo 132-0035 Japan
}

\begin{abstract}
Effect of temperature on drag reduction behavior of quaternary ammonium salt cationic surfactant solutions with sodium salicylate (NaSal) was investigated in terms of 1) alkyl chain length and 2) number of 2-hydroxyethyl groups. Characterization concerning DR effect, pressure loss, first normal stress difference $\left(N_{1}\right)$ and aggregate size for $\mathrm{NaSal} /$ cationics solutions were carried out. NaSal/cationics solutions containing above $40 \mathrm{~nm}$-sized aggregation had a large DR effect ranged from $65-80 \%$. However, the effect suddenly changed to $5-7 \%$ below $30 \mathrm{~nm}$ in aggregate size. The aggregate size apparently plays an important role in DR effect.
\end{abstract}

